\title{
The Tendency of Transition from Structural to Functional Positions in National Civil Service Agency and the Ministry of Environment and Forestry
}

\author{
Amy Yayuk Sri Rahayu ${ }^{1}$ \\ Krisna Puji Rahmayanti ${ }^{2}$
}

\begin{abstract}
This study aims to highlight the phenomenon of transition from structural to functional positions in government bureaucracy in Indonesia. Since in this modern era, an environmental change strongly influences public organizations which encourage public organizations like bureaucracy must be adaptive. In line with the issuance of Law No. 5/2014 on State Civil Apparatus (ASN), public organizations such as bureaucracy have undergone reform to be structurally lean and functionally rich. Consequently, there is a gradual change that government institutions change from structural to functional positions. The methodology applied is post-positivism. The concept of job analysis in the structure of public organizations is deductively downgraded into its indicators and then used as guidance in qualitative data collection. The result found that, firstly, job analysis is still applied and relevant to determine Administrative and Functional Positions in both government institutions, yet it is not carried out systematically and optimally. Secondly, the trend in the tendency of transition from structural to functional positions in both government institutions is due to the misperception of the employees towards Functional Positions.
\end{abstract}

\section{Keywords:}

structural position; organizational change; functional position; civil state apparatus; organizational structure

\section{Introduction}

Organization needs to change and adapt to overcome challenge. Vielmetter and Sell (2014) predict that the work patterns of an organization will undergo changes caused by six current dominant factors, namely globalization 2.0, environmental crisis, individualization and pluralization of values, digital era, demographic change, and technological convergence. One example of a notably frequent change in bureaucracy is the use of ICT as a form of innovation and a consequence of digital era in different parts of the world ((Puspitasari, L., \& Ishii, K, 2016; Wamuyu, P. K., 2017; Kyriakidou, V., Michalakelis, C., \& Sphicopoulos, T, 2011; Sujarwoto, S., \& Tampubolon, G., 2016; Okunola, O. M., Rowley, J., \& Johnson, F, 2017; Philip, L., Cottrill, C., Farrington, J., Williams, F., \& Ashmore, F, 2017; and Nishijima, M., Ivanauskas, T. M., \& Sarti, F. M, 2017).

\footnotetext{
${ }^{1}$ Public Administration Department, Faculty of Administrative Sciences, Universitas Indonesia. Email: amy_soeroso@yahoo.com

${ }^{2}$ Public Administration Department, Faculty of Administrative Sciences, Universitas Indonesia.

Email: krisnarahmayanti@ui.ac.id.
} 
Rapid changes related to organizational adaptation to the environment are increasingly contagious as viruses, including in bureaucratic organizations. Modern organizations will develop with their own genius, pyramidal, centralized, and complex mechanisms known as a bureaucracy that is not in line with contemporary reality. Adaptation, problemsolving, and interim systems of various specialists are coordinately linked together. It is an original form that will gradually replace bureaucracy (Styhre, 2007).

The phenomenon of bureaucratic change emerges in several countries. Singapore, for example, has started bureaucratic reform since 1980 and has been named one of the best countries in terms of efficient bureaucracy and reliable quality of public services (Political \& Economic Risk Consultancy/PERC, 2012). South Korea laid the foundations of administrative reform through various laws and regulations, such as the ethics of civil servants, social purification movements, civil service awareness reform, control of retired civil servants, and recruitment of civil servants (Hwang, 2004). Meanwhile, Chinese administrative reform was then accomplished by downsizing the number of ministries, departments and government institutions from 100 to 61 institutions and 30,000 members of the party cadres were given early retirement. As a result, Deng created an efficient, clean, anti-corruption, serving and lean bureaucracy which makes China currently grows into a strong economic country (Prasojo, 2008).

Bureaucratic reform in Indonesia was started with the issuance of Law No. 17 of 2007 on National Long Term Development Plan 2005-2025 mandating that the development of the state apparatus be carried out through bureaucratic reform to support the success of development of other fields. As the manifestation of national commitment to carry out bureaucratic reform, the government has set bureaucratic reform and governance to be the top priority in Presidential Regulation No. 5 of 2010 on National Medium Term Development Plan 2010-2014 which then then followed up by the issuance of Presidential Regulation No. 81 of 2010 on the Grand Design of Bureaucratic Reform (GDRB) 2010-2025.

In the midst of bureaucratic issues that still have not improved, Law No. 5/2014 on Civil State Apparatus (ASN) emerges and becomes the legal protection of reform of ASN in Indonesia. Meanwhile, ASN currently still has issues that include: 1) unclear manpower planning; 2) unclear distribution of education for ASN; 3) unclear and inefficient organizational design, authority and work; 4) unprofessional implementation of basics of human resource management, and 5) weak enforcement of discipline, integrity, and good governance (Krisbiyanto, 2012). Of the five issues presented by Krisbiyanto, the third issue is closely related to the factual problem of this study, that unclear and inefficient organizational design, authority and work will greatly affect the productivity of an organization.

Regarding these issues, bureaucracy in Indonesia stands out in the complexity of fat organizational structure because it is rich in administrative positions and poor in functional positions. The positions consist of: First, Structural Positions, namely a firm position in the organizational structure. Structural positions are arranged in levels through echelonization, starting from the lowest level or Echelon IV to the highest level or Echelon I. The examples of structural positions in the Center from the lowest echelons are Section Head (Echelon IV), Division Head (Echelon III), Director (Echelon II), Director General (Echelon I), and Secretary General (Echelon I). Structural Positions in Regions are Secretary (Echelon II), Head of Department (Echelon III), and Section Head (Echelon IV); Second, Functional Positions, namely unlisted technical positions in organizational structure. However, in terms of function, this position is required in the 
main duties of the organization, namely as an expert planner, supervisor/auditor, examiners, doctors, researchers, etc. The regulation related to the appointment of civil servants in structural positions is the Government Regulation No. 13 of 2002 on the Appointment of Civil Servants in Structural Positions (Official Portal of the Ministry of Research, Technology, \& Higher Education, 2016)

The issuance of Law No. 5 of 2014 on State Civil Apparatus, replacing Law No. 43/1999 on the Principles of the Personnel of the Republic of Indonesia, is a fundamental change to the personnel system of the Republic of Indonesia. First, the employees meant are Civil Servants and Government Employees to Work Agreement (PPPK).

Meanwhile, in Law No. 43/1999, PPPK doesn't exist. Another interesting fact is Law No. 5/2014 mentions three characteristics of Positions, namely Administrative Positions, Functional Positions, and Positions of High Leadership. Meanwhile, the Personnel Law only acknowledges two Positions, namely Structural and General Functional Positions (JFU). The term of Positions of High Leadership means a group of high positions in Government institutions that may only be occupied by ASN, such as the positions of Secretary General, Director General, etc. Meanwhile, Administrative Positions are a group of positions containing the functions and duties related to public services and government administration and development. The positions are occupied by ASN as well. Furthermore, Functional Positions are a group of positions containing the functions and duties related to functional services based on certain expertise and skills. Furthermore, the Law explains that Functional Positions consist of Functional Positions of Expertise and Functional Positions of Skill (Law No. 5 of 2014 on State Civil Apparatus).

Currently, there is a tendency for ASN to target and attempt to move to Functional
Positions, particularly Functional Positions of Expertise (based on certain competencies). Obviously, it does not matter if the relevant individual truly has the expertise as required by the relevant institution, meaning that there is a good planning or job analysis carried out due to necessity. Functional positions can be appointed through three mechanisms, namely ASN recruitment, in-passing, and transfer of positions (mutation). Recruitment certainly requires a good planning through job analysis. Meanwhile, transfer of position seems chaotic and less organized, not to mention the unclear mechanism.

The phenomenon of transition from Administrative to Functional Positions apparently is not followed by the preparedness of the Government to provide the formation of Functional Positions. Thus, the recruitment requires a long waiting period due to bezetting (the placement cannot be fulfilled due to lack of formation). Meanwhile, the implementation of transfer of job is also complicated. For example, it is not transparent since it comes from a cause and desire of an individual to move to Functional Positions even though the relevant individual does not have the expertise required by the organization or institution. Most individuals reason that Functional Positions are considered to have a better and prouder future because of promotion system every two years and clear performance measurement and incentives compared to Administrative Positions with promotion system every four years and looser performance measurement.

As a result, almost all Government Institutions face serious issues, namely: 1) every Functional Position of Expertise requires a Supervising Institution, for example Supervising Institution for Planner Position is National Development Planning Agency (BAPPENAS) or Regional Development Planning Agency (BAPPEDA) in regions. Supervising Institution for auditor is the State Audit Agency (BPK-RI). Preparedness and 
coordination with the Supervising Institutions are another issues. Therefore, the improper plan will lead to a long waiting period for an appointment. The related ASN should wait for the appointment decree as Functional Official; 2) the tendency of transition to Functional Positions is frequently not followed by sound and clear socialization. The employees seem to perceive that should they become Functional Officials, they can be promoted every two years, obtain bigger functional benefit, and can exchange places back to structural positions. Promotion in Functional Positions is carried out every two years, while promotion in Structural Position is carried out every four years. However, promotion in Functional Positions must meet some predetermined credit scores as performance standard. Similarly, in terms of benefits, the raise of benefits use single salary instead of general or structural-functional benefits; 3) the placement of Functional Positions in the middle of Administrative Positions also requires clarity of division of task. The leadership must be able to perform the division of duty carefully in accordance with the main duties and functions of Functional Positions and differentiate them from those of the Administrative Position. Therefore, the promotion of Functional Positions may improve by increasing the credit score without having to compete for work; 4 ) the appointment of Functional Positions is certainly inseparable from the acceleration of bureaucratic reform in providing professional and reliable ASN. Therefore, behind the encouragement, the Center should consider about how each K/L and Institutions in Regions can map the needs of Functional Positions of Expertise accustomed to the objectives and achievements of vision and mission of each Institution as a whole. It is not appropriate if Indonesia has a large number yet unnecessary or unused Functional Officials because of its low quality and unsuitable competence and achievement of organizational objectives.
This study uses two institutions as the sample, namely National Civil Service Agency (BKN) and the Ministry of Environment and Forestry (KLHK). The reasons are: First, $\mathrm{BKN}$ is the Agency operating the tasks as the management of ASN in Indonesia. Thus, it becomes the role model and portrait of the process of transfer of ASN from Administrative to Functional Positions. Second, KLHK is currently a merger between two Ministries, namely the Ministry of Environment and the Ministry of Forestry. The merger can structurally imply the loss of certain Functional Positions and the emergence of other Functional Positions, or a combination of both. Sources from KLHK state that Functional Positions for environmental supervisors will be large enough to reach an estimated 22,000 people. Currently, there are only 1,000 people. By merging with the Ministry of Forestry, it is predicted that the need for Functional Positions for Forest Supervisor will also increase.

The issue in KLHK is that there is a tendency to submit formation to high Functional Positions. However, it cannot be fulfilled due to various issues. Table 1 illustrates the increasing rate of formation submission for Functional Positions from 2010 to 2014. The increase is in the range of more than $50 \%$ compared to the Administrative Positions. However, there is still a gap between formation submission and reality. The government can meet the formation of Functional Positions for $37 \%$, meaning that there will be issues such as long waiting period for placement and the possibility of a mutation back to Administrative Position. Table 2 shows that the highest tendency of formation submission for Functional Appointment occurs in 2010 (realization of $21.37 \%$ ) and 2011 (realization of $35.63 \%$ ). Afterward, from 2012 to 2014, despite high formation submission for Functional Positions, the realization is very low, less than $2 \%$ (Arifin, 2017). Prior to the enactment of UU ASN, there was general functional position 
which was changed since the implementation of minister regulation about nomenclature and regulation about public servant in UU No 43 Year 1999 which had regulate about the Functional and Administrative functional with no specific requirements.

Table 1.

Gap of Formation Submission and Functional Appointment

\begin{tabular}{cccc}
\hline Year & \multicolumn{2}{c}{ Formation Submission } & Functional \\
\cline { 2 - 3 } & $\begin{array}{c}\text { Administrator } \\
\text { Position }\end{array}$ & $\begin{array}{c}\text { Functional } \\
\text { Position }\end{array}$ & $\begin{array}{c}\text { Appointment } \\
\text { Apsion }\end{array}$ \\
\hline 2010 & 5597 & 9092 & $1943(21.37)$ \\
2011 & Moratorium & Moratorium & $2612(35.63)$ \\
2012 & 7235 & 7339 & - \\
2013 & 19539 & 39244 & $539(1.37)$ \\
2014 & 11007 & 43800 & $211(0.48)$ \\
\hline
\end{tabular}

Source: Fahrani, 2016

Meanwhile in BKN, the formation submission for functional positions in BKN also has a significant increase, meaning that functional positions in BKN units have been developed through the appointment of employees into functional positions compared to formation submission for administrative positions. In 2014, the submission for functional positions increases from 39,244 to 43,800 or $11.61 \%$, while the submission for administrative positions decreases from 19,539 to 11,007 or $43.67 \%$ (Mulyadi, 2017) (Rosyani, 2017).

In line with the increase of formation submission for Functional Positions, BKN currently has also developed 17 functional positions from 142 available functional positions and has appointed 490 employees or $37 \%$ of the total employees into functional positions. As a government board that has the authority to carry out guidance and management of ASN nationally, BKN becomes the role model in ASN employment management. It raises several questions: Has the development of nomenclature of Functional Positions been based on job analysis as regulated in the Law? Is the development of functional positions truly based on consideration of needs of competence in achieving current objectives of BKN?

\section{Method}

The approach applied in this study is post-positivism (Yang, 2007; Denzin, 2005, Creswell, 2009). Deductively, the concept of job analysis becomes relevant to be used as information about the tendency towards Functional Positions. The data are collected qualitatively through in-depth interviews with key informants. The interview guidelines are derived from the implementation of the concept and stages of job analysis by Dessler (2013). The validity of qualitative data is measured through triangulation with other key informants and comparing the data with applicable regulations to minimize subjectivity. The informants of this study are 13 people consisting of related officials whose duties and authority are to manage Functional Positions in BKN and KLHK and the employees involved in mutation from Structural to Functional Positions. Indepth interviews with the informants were carried out from April 1 to June 20, 2017.

\section{Result and Discussion}

The phenomenon of transition from Structural to Functional Positions can be observed from two perspectives. In terms of organizational structure, it is seen more efficient because the number of Structural Positions is reduced. It means that the Government organizations become leaner and more efficient and able to reduce the gap due to a long hierarchy. This perspective also accommodates the notion that the values of the structure of government organizations, or commonly referred to as bureaucracies, should not lie in the size of the structure, but instead how the hierarchy can be used efficiently in responsive and non-inhibiting public services.

From the term of Functional Position, the phenomenon of transition of position should further strengthen the organization in 
achieving its objectives. Functional Positions are a position occupied by officials who have certain competencies and skills. These competencies and skills are required by the organization to achieve its goals. If a structural official is appointed through a career path, then a functional official is appointed due to competencies and skills required by the organization. The performance and accountability of Functional Officials are usually clearer and measurable, as well as their incentives and take-home pay. In an initial study on several employees in both institutions, the employees are found to be happy for occupying Functional Positions, due to clear performance measurement and incentive obtained.

Therefore, referring to Institutional Theory (Frederickson, 2012), the organizational structure of public administration should be associated with outcome achievement. The following is the analysis of the findings found in the field, including the investigation of 6-stage procedures in job analysis in the KLHK and BKN-RI.

\section{Informational Chaos}

The concept of job analysis presented by Dessler (2013) presents a procedure in which an organization can determine the number of positions required through a systematic mechanism, among others are planning or design based on the information about the needs of positions and comparison with the ability to fulfill them, for example, the formation, available competencies, training, the necessary finance or budget, and performance measurement standards. The information is required to plan for the procurement of positions within an organization, primarily sourced from the internal organization, such as complete employment data, employee profile that includes the skills and competencies that are in line with the needs, employment history, work load, and current work environment. In addition to the existing data, it is possible to carry out assessments to determine the development of employee capability through in-depth interviews and questionnaire.

In the early stage of the procedure by Dessler (2013), it is obtained that: First, complete and accurate information about competence as well as track record of performance and development of employees do not exist, particularly in a systematic and updated storage system. Therefore, the data of competence and development of thousands of employees in a Government Board are difficult to be tracked. The information is important to determine various policies, like personnel administration. This situation also implies that the data and information recorded into the track record of employees in government organizations are still not considered important. In the context of determining the positions, it is a big question mark.

Second, if the information from the archive cannot be expected, another alternative is the direct data obtained from interviews and questionnaires in accordance with the Regulation of the Ministry of Administrative and Bureaucratic Reform No. 33/2011. Such data should be more valid and updated because they are taken directly from the source. Apparently, this mechanism is difficult to carry out, so that the necessary information is not optimal. Most informants state that it is difficult and time-consuming to collect employee data. In addition, the results are less optimal. The employees of both institutions assume that such information is unnecessary because it is time-consuming. Another informant clarifies that the questionnaire is still applied one-by-one rather than online. Apart from time-consuming, it is inflexible. Another informant explains that information about the employees and their job description can be obtained through business process (BP). Unfortunately, both Government Institutions do not have BP yet.

\section{False Information Review}

There is an urgency to review all relevant information which is the basis for job analysis 
(to review relevant background information, such as organization charts, process charts, and job description). In the initial stage, informational chaos is found to be caused by weak employment information system and weak employee awareness in terms of gathering information about themselves. This aspect will clearly affect the next stage. Nonetheless, if job analysis is still carried out, it is presumed that there are false data.

Almost all informants perceive that job analysis is notably crucial, but they also state that job analysis carried out in their institutions is not optimal. The Regulation of the Head of BKN No. 12 of 2011 on Job Analysis states that job analysis is an important requirement in determining a position. Otherwise, it becomes a unity in Human Resource Management in Government Institutions. The role of job analysis is irreplaceable in arranging the required positions in relevant institutions, particularly Functional Positions.

The most obvious impact as a result of weak data and information in job analysis is the emergence of various issues, namely discrepancy between the number of employees qualified for Functional Positions and the number of formation. The frequent long waiting period for the availability of formation causes uncertainty. It is harmful on a national scale because the employees become passive, leading to inefficiency and ineffectiveness.

In addition, the formation provided in functional positions should be occupied by people or employees who have appropriate competences. The reality is truly far from expectation. Bima Wibisono, the Head of BKN RI, explains that in a study of competency assessment (talent pool) carried out by BKN to 696 Officials of High Leadership (JPT) and 2,670 administrators, it is found that the quality of ASN in terms of competence and potential is still low, where thousands of ASN cannot work in teams and lack of innovation and motivation. It indicates that the academic degrees of ASN does not guarantee their competence. In fact, competence is required in the placement and accuracy of position (Ben Wibisono in Sindo News online, December 2017)

\section{Positions are Selected without Tangible Data/Information}

The third stage is to select positions required by the organization (to select representative positions). At this stage, ideally, the process of job analysis generates various alternative positions required and selects the most required positions by the organization in order to achieve its objectives. Therefore, the determination of positions is more effective. A study by Arifin (2017) notes that KLHK currently has 33 types of functional positions. Some of them must be revised and adapted because they are not in accordance with the requirements and even no longer required by the organization. Improved positions consist of functional positions for Environmental Development Controller/ PEH) and Environmental Supervisor (PLH), while the removed functional positions are the position for Community Self-Mobilization.

KLHK actually still requires functional positions. The current number of Functional Officials in KLHK is 6,587 (37.05\%) of total 17,780 employees. According to Arifin (2017), the existing number of functional officials are inadequate and will continue to be added, either through recruitment of new employees (Candidates of PNS) or the shortcut (transfer from executive and structural positions to functional positions).

The findings of the study by Mulyadi (2017) on Functional Positions of National Civil Service Agency (BKN-RI) show that functional positions are required to support the efforts of an organization to achieve its objectives. The findings state that functional positions are able to improve performance because they are composed of people who have expertise. There are 575 employees in BKN occupying 
functional positions consisting of 20 functions. Empirical evidence from the study also implies that job position based on workload is far from perfect. This condition affects the actual needs of the organization, and it is unfair in nature. Therefore, there is still a high probability that there are many unknown functional positions to be revised or refined. Current evaluation using credit evaluation cannot create a real picture of the performance because it tends to be used as an administrative requirement to raise the rank of the employees. This condition implies that the relationship between job classification in functional positions and achievement of organizational objectives lies in the gray area.

The informants also state that the main difficulty for job analysis in both institutions does not lie in the process, but in the application, since subsequent to the successful performance of Job Analysis, the results will be the basis for the placement of employees. It implies a redistribution of employees and frequently results in employees' resistance since they feel comfortable in their original positions. Another issue is that the use of Job Analysis merely covers in-passing. It can be said that the selection of job positions required is still difficult because of resistance or the issue of "order" in in-passing.

\section{Missing Link with Organizational Objectives}

Job Analysis is used to link between organizational objective and positions. Dessler (2013) encourages us to actually analyze job by activities, working conditions, human traits, and abilities needed to reform the job. The informants on both institutions state that apparently Job Analysis has not referred to organizational objectives, particularly Functional Positions, but on the predetermined duties and functions.

In fact, since the election of President Jokowi, the direction of vision and mission of the Republic of Indonesia has changed into
NAWA CITA (Nine Objectives of Indonesia), meaning that all executive institutions have mission and vision derived from NAWA CITA. Unfortunately, it is not found even understood in the practice of job analysis in both institutions.

The results of the interview still revolve around the understanding that Job Analysis is used to merely determine in-passing and formation. Even though it has been carried out since 2012, the uses and objectives of Job Analysis associated with achieving organizational objectives are still unaccomplished. The Head of BKN RI, Ben Wibisono, in the past Research and Development of BKN 2016 states that numerous studies on Functional Positions in BKN have not analyzed the importance of functional positions and determinants of organizational objectives. It is further said that Functional Positions should be directed at the competence of employees in line with the achievement of NAWA CITA because all Government Institutions should refer to NAWA CITA.

\section{The Lack of Involvement of Leadership in Employment Verification}

In this stage, employment verification is carried out to employees and supervisors (to verify the job analysis information with the worker performing the job and with his or her immediate supervisors). Employment verification is carried out to obtain information about compatibility between the new position and the competence of the official or employee occupying the new position. It means 'the right man on the right place,' ensuring that the official is worthy to occupy the position.

The condition may be slightly different between public and private sectors. In private sectors, employment verification is essentially carried out frequently, particularly in the process of job analysis. However, it is different from Government Institutions. Along with the appointment of an employee into Structural and 
Functional Positions, the duties and functions of the employees are already considered given. Since the beginning of the recruitment, anomaly frequently occurs. For example, an individual is academically noted to have competence in agriculture, but occupying position in the field of finance. This condition is prevalent in Government Institutions.

One of the most important parties in determining that a Job Analysis is correct and feasible to implement is the leadership of the organization, or at least the HR manager. The informants stated that the involvement of the leadership or HR manager is less and even almost non-existent. The leadership considers job analysis a temporary and unimportant job compared to other achievements. Conceptually, the leadership should be able to form a team of verification or quality control of job analysis, involving the HR Manager/Head of the Bureau of Personnel, sample of employees and supervisors, as well as a team of data analysis to review the results of job analysis. All the parties involved should coordinate intensively. However, it is difficult to accomplish. Time and activities become obstacles. In fact, in the Regulation of the Head of BKN No. 12/2011, the most important stage of Job Analysis is the validation of results.

The informants stated that it should start from the leadership since the leadership is the most responsible party for the placement and needs-mapping of the employees. The second is the employees because it concerns their fate. The third is the team of data analysis; the quality of job analysis is highly important since it concerns the fate of the employees. However, in both institutions, there is no mechanism to mobilize people collaboratively. In addition, there is a crucial matter concerning the team of data analysis. The informants agree that the quality of the team of data analysis is still far from expectations because it does not represent each work unit analyzed, has weak competence, undergoes a frequent change of members of the team, and involves conflict of interest.

\section{The Difficulty in Compiling Job Description}

The final stage of Job Analysis procedures is to develop a job description, namely clear job descriptions, specifications that differentiate from other positions, as well as skills and competencies required to support Functional Positions. The guidelines are the Regulation of the Head of BKN No. 12/2011.

Once again, the validity of data is still doubtful. Some informants argue that the questionnaire for employee also does not reflect the real conditions, particularly in calculating the output volume of activities. Thus, job description is unclear and incomplete. Meanwhile, the requirements or specifications still refer to formal education and are not regulated by the competencies appropriate with organizational objectives.

In KLHK, the merger between the Ministry of Forestry and the Ministry of Environment leads to confusion concerning which type of nomenclature should be reduced and which one should be added. The type of nomenclature of Functional Positions is supposed to be reduced or adjusted to achieve the objectives of the combined KLHK. However, the calculation of type of nomenclature of required functional positions has not been carried out yet.

The objective of merger between the two ministries among others is for the efficiency of the organizational structure. It is not merely to merge and become a large entity. Therefore, the formation of the procurement of new positions must be balanced, some deleted or merged, and some replaced with new formations. Associated with the formation, KLHK requires the formation of functional officials for forest supervisors. However, it still cannot be fulfilled. A more alarming fact is that most of Functional officials cannot meet the required number of credits as an indicator that 
the officials concerned are able to demonstrate their function well. As a result, they are unable to meet the number of credits within two years so that they should be exempted temporarily from their position. It also raises another issue and causes organizational inefficiency since parts of human resources do not generate any output.

Most informants suggest that the actual procedures of Job Analysis for Functional Positions, in addition to time-consuming and depending on employee information, are deemed to be easier to follow and clearer than Job Analysis for Structural/Administrative Positions. The activities and credit number of Job Analysis for Functional Positions have been clearly determined. The difficulty lies only in the calculation of the volume of activities and employee information. Meanwhile, the Job Analysis for Administrative Positions involves notably diverse activities and variants, work completion time that is difficult to determine, as well as work volume.

It is interesting to observe the analysis of six stages by Dessler (2013). First, the concept of Job Analysis is considered still relevant to determine functional or administrative positions required by an organization. It is also expressed in the study by Baruch and Lessem (1995) on whether Job Analysis is still required in all levels of organization. Fahrani (2016) also explores similar issue in a similar study on planning model of Functional Positions. The point is that the development of positions through appointment into Functional Positions should be carried out with a good planning, hence it is not merely limited to the provision of career certainty. A study by Yoon and Kim from South Korea (2014) explains that the information of positions related to main tasks will determine the output of employees or their performance and impact the achievement of the organization. It is supported by the findings of a study by Tanumihardjo, Hakim, and Noor (2013) that Job Description and Specification have positive influence on employee performance.

In this case, Job Analysis is still considered relevant to be implemented as regulated in the Regulation of the Head of BKN No. 12/2011. The implementation, however, is still weak and less systematic. In fact, Job Analysis is the basis of the activities of human resource management because it focuses on the content, the need, and the context of the positions. Armstrong (2006) refers to it as the role analysis. Role analysis provides the information required to generate role profile to be used for the recruitment, training and development, performance management, and job evaluation. In another sense, role analysis is a process to find out what people expect to achieve when carrying out their work as well as the competencies and skills they need to meet for those expectations. The result of role analysis is role profile that defines the results expected by the holders by showing the key results or accountability. This profile also displays a list of competencies required to work effectively in what roles the holders need to know and be able to carry out.

Second, the phenomenon of transition from Structural/Administrative to Functional Positions requires conceptual and operational awareness of the importance of Job Analysis systematically, in which the leadership of the organization and the employees are a work team in creating a common interest. Thus, they should have similar understanding of the essence and the purpose of Job Analysis. Stone (2011) states that job analysis is a systematic investigation of the tasks, duties, and responsibilities of a job and the necessary knowledge, skills and abilities a person needs to perform the job adequately. The less optimal and well-planned implementation of Job Analysis will not be able to correctly capture the competencies, skills, and abilities required. The lack of concern from the leadership of the organization and the employees generate low accuracy of employee data/information 
required. Furthermore, long appointment process and lack of coordination between units, as well as occupational requirements that have not relied on the expertise and competence are failures to capture the essence and objective of Job Analysis.

The employees have a wrong perception of Functional Positions. They are slow to fill out the questionnaire for data collection and assume that Functional Positions are more "profitable" in career certainty and incentives. It is a misperception that must be straightened. The many candidates of functional officials exempted from Functional Positions indicate that their perception is wrong. In addition, the employees are also unaware that Functional Positions require competence and expertise in accordance with the achievement of the vision, mission, and objectives of the organization and do not merely rely on formal education. "Blur competences" still dominate Functional Positions in both institutions. The blur competences may be due to either less optimal implementation of Job Analysis or unpreparedness of the Education \& Training Institutions designated as the Administering Institutions for Functional Officials. Coordination with these institutions is important to synchronize the budget, planning, and scheduling of training.

\section{Conclusion}

The milestone in the development of bureaucratic organization is started with bureaucratic reform, particularly environmental changes affecting organizational structure. Lean structure with rich function is the current trend. It is mandated by Law No. 5/2014. Therefore, BKN and KLHK have a solid foundation to make a change in that direction. The phenomenon of transition from structural to functional positions is perhaps a way to achieve bureaucratic reform; nevertheless the wrong conception of the meaning of Functional Positions eventually generates a "migration" toward functional positions that are not necessarily in accordance with the required competencies of the organization. Employee perception of Functional Positions as "more certain and comfortable" position is a misperception that is never straightened by the institutions through proper socialization and education.

Job Analysis (for Administrative and Functional Positions) is still considered relevant and able to provide good data on the necessity of Functional Positions. The failure of wellplanned Job Analysis is caused by the low awareness and involvement of leadership of organizations and the employees, resulting in weak and inaccurate job analysis, leading to the discrepancy or gap between the formation and realization of placement.

Recommendations provided for two institutions, namely BKN and KLHK, are as follows: First, to carry out a socialization about Functional Positions, the process of recruitment, the rights and responsibilities of the officials, the fulfillment of the performance, the implications should the performance be not fulfilled, and others; Second, the institutions have to plan a thorough Job Analysis, provide a sufficient budget, and create a system of innovation or electronic job analysis that can be carried out systematically and online by Job Analysis Team; Third, to carry out collaborative governance management of Job Analysis between central and regional governments as well as between regional governments to create an exchange of experience, competence, and excessive formation between Government Institutions. Fourth, to build an online system to enable employees to fill in the questionnaire as part of a Job Analysis Mechanism so that busy employees can file it at home more efficiently.

\section{References}

Arifin, Agus M. (2017). Implementasi Analisis Jabatan pada Jabatan Fungsional di Instansi Pemerintah (Kasus di Kementerian Lingkungan 
Hidup dan Kehutanan). Unpublished Dissertation. Depok: Universitas Indonesia. Armstrong, Michael. (2006). A Handbook of Human Resource Management Practice (10th ed.). London: Cambridge University Press.

Baruch, Y., \& Lessem, R. (1995). Job analysis: Can it still be applied? Indications for various organizational levels. International Journal of Career Management, 7(6), 3-9. doi:10.1108/09556219510098055

Denzin, N. K., \& Lincoln, Y. S. (2005). The Sage handbook of qualitative research. Thousand Oaks: SAGE.

Dessler, G. (2017). Human resource management (13thed.). Boston: Pearson Higher Education.

Fahrani, S., N. (2016). Model perencanaan Pegawai Negeri Sipil (studi kasus di Jabatan Fungsional Tertentu). Jakarta: Center for Employment Assessment and Research - BKN.

Frederickson, H. G. (2012). The public administration theory primer. Boulder: Westview Press.

Krisbiyanto, N. (2012). Mengurai Masalah PNS dengan Pendekatan SDM. Retrieved March 9, 2017, from https://portalhr.com/komunitas/ opini/mengurai-masalah-pns-denganpendekatan-sdm/

Kyriakidou, V., Michalakelis, C., \&Sphicopoulos, T. (2011). Digital divide gap convergence in Europe. Technology in Society, 33(3-4), 265270. doi:10.1016/j.techsoc.2011.09.001

Mulyadi, D. (2017). Analisis Implementasi Pengangkatan Jabatan Fungsional dalam Pencapaian Tujuan Organisasi di Kantor Pusat Badan Kepegawaian Negara. Unpublished Dissertation. Depok: Universitas Indonesia.

National Development Planning Agency. (2012). Reformasi Birokrasi: Telaah Kekinian dan Prospeksi Solusi. Jakarta.

Nishijima, M., Ivanauskas, T. M., \& Sarti, F. M. (2017). Evolution and determinants of digital divide in Brazil (20052013). Telecommunications Policy, 41(1), 1224. doi:10.1016/j.telpol.2016.10.004
Okunola, O. M., Rowley, J., \& Johnson, F. (2017). The multi-dimensional digital divide: Perspectives from an e-government portal in Nigeria. Government Information Quarterly, 34(2), 329-339. doi:10.1016/j. giq.2017.02.002

Philip, L., Cottrill, C., Farrington, J., Williams, F., \& Ashmore, F. (2017). The digital divide: Patterns, policy and scenarios for connecting the 'final few' in rural communities across Great Britain. Journal of Rural Studies, 54, 386-398. doi:10.1016/j.jrurstud.2016.12.002

Prasojo, E., \& Kurniawan, T. (2008). Reformasi Birokrasi dan Good Governance: Kasus Best Practices dari Sejumlah Daerah di Indonesia. Speech presented at The 5th International Symposium of Journal Anthropology.

Puspitasari, L., \& Ishii, K. (2016). Digital divides and mobile Internet in Indonesia: Impact of smartphones. Telematics and Informatics, 33(2), 472-483. doi:10.1016/j.tele.2015.11.001

Rosyani, Y. (2016). Analisis perencanaan dan pengembangan karir pegawai pada pengisian formasi Jabatan Pengawas di Badan Kepegawaian Negara. Depok: Faculty of Social and Political Sciences.

Stone, R., J. (2011). Human resource management (7th ed.). Australia: John Willey \& Sons Australia, Ltd.

Styhre, A. (2007). The innovative bureaucracy: bureaucracy in an age of fluidity. London and New York: Taylor \& Francis Group.

Sujarwoto, S., \& Tampubolon, G. (2016). Spatial inequality and the Internet divide in Indonesia 2010-2012. Telecommunications Policy, 40(7), 602-616. doi:10.1016/j. telpol.2015.08.008

Tanumihardjo, S., Hakim, A., \& Noor, I. (2013). Pengaruh analisis jabatan terhadap kinerja pegawai (studi pada Sekretariat Daerah Pemerintah Kabupaten Malang). Malang: Public Administration Department, Faculty of Administrative Sciences, Universitas Brawijaya. 
The Ministry of Administrative and Bureaucratic Reform. Makna dan Tujuan Reformasi Birokrasi. Retrieved from http:// www.menpan.go.id/kedeputian-reformasibirokrasi/530-makna-dan-tujuan

The Republic of Indonesia. (2014). Law No. 5 of 2014 on State Civil Apparatus. The State Gazette of the Republic of Indonesia of 2014 No 5994.

The Republic of Indonesia. (2000). Government Regulation No. 100 of 2000 on the Appointment of Civil Servants in Structural Positions. The State Gazette of the Republic of Indonesia of 2000 No. 4018.

The Republic of Indonesia. (1994). Government Regulation No. 16 of 1994 on Functional Positions of Civil Servants. The State Gazette of the Republic of Indonesia of 1994 No. 3547.
The Republic of Indonesia. (1999). Presidential Decree No. 87 of 1999 on the Functional Group of Civil Servant Officials.

Vielmetter, G. \& Sell, Y. (2014). Leadership 2030, the six megatrends. New York: AMACOM.

Wamuyu, P. K. (2017). Bridging the digital divide among low income urban communities. Leveraging use of Community Technology Centers. Telematics and Informatics, 34(8), 1709-1720. doi:10.1016/j.tele.2017.08.004

Yang, K. \& Miller, J. G. (2007). Hand book of research methods in public administration. USA: CRC Press, Taylor and Francis Group. Yoon, H., \& Kim, S. (2009). A study on the job analysis of public libraries in Korea. Aslib Proceedings, 61(6), 504-541. doi:10.1108/00012530911005508 